\title{
TOXICITY REDUCTION IN LEATHER TANNING WASTEWATER BY IMPROVED COAGULATION FLOCCULATION PROCESS
}

\author{
G. LOFRANO ${ }^{1}$ \\ V. BELGIORNO ${ }^{1}$ \\ M. GALLO ${ }^{2}$ \\ A. RAIMO ${ }^{3}$ \\ S. MERIÇ ${ }^{1^{*}}$
}

Received: 30/5/2005

Accepted: 15/2/2006

\author{
${ }^{1}$ Department of Civil Engineering \\ University of Salerno \\ 84084 Fisciano (SA), Italy \\ ${ }^{2}$ Campania Regional Agency for Environmental Protection \\ Naples, Italy \\ ${ }^{3}$ Consorzio Disinquinamento Solofra, Italy
}

\begin{abstract}
The wastewater of leather industry which is one of the most widespread industries having large amount of water consumption and very high pollution loads, may be characterized by several key parameters including toxic pollutants exhibiting toxicity. Therefore the effluent of leather tanning industry must be handled carefully during both treatment plant design and operation.
\end{abstract}

The aim of this study was to improve the coagulation process for toxicity reduction of raw wastewater taken from a leather tanning district central treatment plant (Solofra, (Avellino, Southern Italy). A series of jar test experiments on three samples taken between February and July 2005, were performed using ferric chloride, ferrous chloride, aluminium sulphate and polyaluminium ferric chloride (PAFC).

The optimum coagulation conditions for the first sample were determined as $8.5 \mathrm{pH}$ and 900 $\mathrm{mg}^{-1}$ dose of PAFC with the addition of $\mathrm{Ca}(\mathrm{OH})_{2}$ which resulted in a $76 \%$ COD and $98 \%$ TSS removal and more than $50 \%$ of D. magna immobilization (at $50 \%$ dilution) reduction. Coagulation experiments performed on second and third samples showed that PAFC resulted in the highest COD removal among the coagulants tested The results that PAFC, recently developed coagulant, is the most promising one for leather tanning wastewater, thus, improved coagulation followed by biological treatment can result in safe effluent to aquatic environment.

KEYWORDS: leather tanning industry, coagulation process, poly-aluminium ferric chloride (PAFC), ferric chloride, aluminium sulphate, ferrous chloride, toxicity removal, Daphnia magna

\section{INTRODUCTION}

Italy produces more than $50 \%$ of European leather demand with 190 millions of $\mathrm{m}^{2}$ per year, corresponding to 1.050 .000 t per year of skin [1]. The transformation of raw or semi-pickled skins into commercial products requires high water consumption and the use of many chemical products. Therefore, leather tanning industry is classified with high organic loads and priority pollutants such as sulphite, chromium, synthetic tannins (Syntan), biocides [2, 3]. Coagulation-flocculation (CF) process, generally using inorganic coagulants such as aluminium sulphate (alum), ferric chloride $\left(\mathrm{FeCl}_{3}\right)$, ferrous sulphate $\left(\mathrm{FeSO}_{4}\right)$ has been applied to leather tanning wastewater to reduce organic load and suspended solids as well as to remove toxic substances, e.g. chromium before biological treatment. Ates et al. [4] investigated the effectiveness of alum and $\mathrm{FeCl}_{3}$ based-CF for the treatment of homogenized inlet of a central treatment plant of leather tanneries district. All experiments resulted in $>70 \%$ of COD removal. Total chromium was also effectively $\left(<5 \mathrm{mg} \mathrm{l}^{-1}\right)$ removed by alum while it 
was almost completely removed using $\mathrm{FeCl}_{3}$ as seen in Table 1. Kabdasli et al. [5] also reported $40-70 \%$ removal of COD and $>99 \%$ of total chromium from leather tanning wastewater using $\mathrm{FeSO}_{4}, \mathrm{FeCl}_{3}$ and alum. Song et al. [6] obtained a removal range of $30-37 \%$ of total COD, $74-99 \%$ of chromium and $38-46 \%$ of SS using $800 \mathrm{mg}^{-1}$ of alum at $7.5 \mathrm{pH}$ for pre-settled tannery wastewater containing $260 \mathrm{mg} \mathrm{l}^{-1}$ of SS, $16.8 \mathrm{mg} \mathrm{l}^{-1}$ of chromium, $3300 \mathrm{mg}$ $\mathrm{I}^{-1}$ of $\mathrm{COD}$ at $9.2 \mathrm{pH}$. They reported that $\mathrm{FeCl}_{3}$ proved better results than alum.

Table 1. The chemical settling of an homogenized raw wastewater from an organized leather tanning district [4]

\begin{tabular}{lcccccc}
\hline Coagulant & Dose & $\mathrm{pH}$ & \multicolumn{2}{c}{$\mathrm{COD}\left(\mathrm{mg} \mathrm{I}^{-1}\right)$} & \multicolumn{2}{c}{ Total $\mathrm{Cr}\left(\mathrm{mg} \mathrm{l}^{-1}\right)$} \\
\cline { 4 - 7 } & $\left(\mathrm{mg} \mathrm{l}^{-1}\right)$ & & Initial & final & initial & Final \\
\hline Alum+polyelectrolite & $600+2$ & 7.5 & 6145 & 1085 & 198 & 4.50 \\
Alum+ polyelectrolite & $400+2$ & 8.5 & 4185 & 950 & 133 & 1.54 \\
$\mathrm{FeCl}_{3}+$ polyelectrolite & $1000+2$ & 8.1 & 4980 & 1140 & 135 & $<0.5$ \\
$\mathrm{FeCl}_{3}+$ polyelectrolite & $750+2$ & 9.2 & 4650 & 1195 & 125 & $<0.5$ \\
\hline
\end{tabular}

Although a big part of the pollutants are removed by pre-coagulation and biological process is able to absorb the toxicants, nitrification process may still be influenced by the presence of bio-inhibitors at low levels [2]. Thus, advanced oxidation processes (AOPs) such as UV, ozone $\left(\mathrm{O}_{3}\right)$, pohotocatalytic oxidation and their combination $[7,8]$, and Fenton reagent [8] have been used as pre-oxidation or post-oxidation of tannery wastewater [9]. However, due to high costs of these processes, CF still remains the more widely used one at present [6].

A number of toxicity monitoring and removal studies have been performed on leather tanning wastewater including acute toxicity on Vibrio fisheri , Daphnia magna [2, 10-11], sea urchins and marine algae [12].

The efficiency of $\mathrm{CF}$ is mainly influenced by raw wastewater characteristics, $\mathrm{pH}$, temperature, coagulant type and dose and mixing velocity [13-15]. To improve the coagulation efficiency as well as to minimize residual coagulants in the effluent [16], new types of coagulations have been developed such as poly aluminium chloride (PAC), poly aluminium silicate (PASiC) and poly aluminium ferric chloride (PAFC) $\left(\left[\mathrm{Al}_{2}(\mathrm{OH})_{n} \mathrm{Cl}_{6-n}\right]_{\mathrm{m}}\right.$. $\left.\left[\mathrm{Fe}_{2}(\mathrm{OH})_{n} \mathrm{Cl}_{6-n}\right]_{m}\right)$ [17-18]. It was reported that PAFC gives better turbidity removal performance in the range of $\mathrm{pH}$ from 7.0 to 8.4. PAFC gives also good colour removal performance on suspension dyes and the actual wastewater. Therefore, PAFC is a high-effective and stable water treatment agent [18].

To our best knowledge, PAFC has not been applied for treatment of tannery wastewater except the CODISO tannery wastewater treatment plant (Avellino, Italy) where this study was performed. Because the previous results evidenced that coagulated samples displayed a severe toxicity on sea urchins and marine algae in CODISO treatment plant [12], this complementary study has been performed to enhance the coagulation efficiency as well as to compare the efficiency of PAFC with ferric chloride, ferrous chloride, aluminium sulphate on samples taken from the effluent of equalization basin (EQ) of the CODISO. Toxicity of raw and coagulated samples was monitored using Daphnia magna which is one of the bioassays referred by Italian Water Quality Discharge limits [19].

\section{MATERIALS AND METHODS}

\subsection{Sampling site}

In the Solofra district, the leather tannery wastewater is treated in a centralized wastewater treatment plant (CODISO) that receives wastewater from approximately 140 factories mostly producing leather for clothing, shoes and tapestry from goat and cattle skin. More than 3000 types of chemicals are used in the tanning process. These factories mostly work on semipickled and de-haired leather. The CODISO receives an inflow of $8,000 \mathrm{~m}^{3} \mathrm{~d}^{-1}$, and consist of an equalization basin followed by a coagulation and flocculation process and biological nitrification. Around $1000 \mathrm{mg} \mathrm{l}^{-1}$ of (PAFC) is currently used as coagulant and an anionic polyelectrolyte $\left(1 \mathrm{mg} \mathrm{l}^{-1}\right)$ as flocculant in the treatment plant [12]. $\mathrm{pH}$ is adjusted over 8.5 using $\mathrm{Ca}(\mathrm{OH})_{2}$ to remove effectively chromium. 


\subsection{Sampling and conservation}

The samples were delivered to the laboratory in $1 \mathrm{~h}$ for chemical analysis and acute toxicity tests. The samples were kept refrigerated at $+4{ }^{\circ} \mathrm{C}$ during analysis.

\subsection{Jar tests}

A series of Jar-test experiments were performed on raw wastewater applying 2 min rapid mixing (RM) at $100 \mathrm{rpm}, 20$ min slow mixing (SM) at $30 \mathrm{rpm}$ and 30 min settling at three $\mathrm{pH}$ values $\left(8.0,8.5,9.0\right.$ using $\mathrm{NaOH}$ or $\mathrm{Ca}(\mathrm{OH})_{2}$ of $5 \mathrm{~g} \mathrm{l}^{-1}$ solution).

CF experiments were performed using PAFC and comparatively with ferric chloride, ferrous chloride, aluminium sulphate and anionic poly-acrylamide-based flocculant (2 $\mathrm{mg} \mathrm{I}^{-1}$, Bierrechimica, Italy) which is currently used in the treatment plant. The dose of the coagulants was varied from 800 to $1200 \mathrm{mg} \mathrm{I}^{-1}$. All experiments were performed at room temperature (20$\left.25^{\circ} \mathrm{C}\right)$.

\subsection{Daphnia magna}

The toxicity of raw and coagulated wastewater was measured using $24 \mathrm{~h} \mathrm{D}$. magna with and without and $50 \%$ dilution [20] to evaluate the influence of wastewater characteristics. For instance, there was found a positive relation between conductivity and juvenile daphnids mortality [21] while over $25 \mathrm{mg} \mathrm{I}^{-1}$ ammonia exhibited $50 \%$ of immobilization of daphnids [22].

Toxicity tests were performed quadruplicate using 5 daphnids in each test beaker with $100 \mathrm{ml}$ effective volume. New born daphnids were grown in the laboratory at $16 \mathrm{~h}$ day light and $8 \mathrm{~h}$ dark periods supplying a 3000 lux illumination. They were fed with Selenastrum capricornutum (300.000 cells $\mathrm{ml}^{-1}$ ) and baker's yeast (Schizosaccharomyces cerevisiae, 200.000 cells mll ${ }^{-1}$ ). Room temperature was kept at $20^{\circ} \mathrm{C} \pm 1^{\circ} \mathrm{C}$ and a minimum $6 \mathrm{mg} \mathrm{l}^{-1}$ of dissolved oxygen was supplied by air filtered through activated carbon. All solutions were prepared using bi-distilled water at $\mathrm{pH}$ 8.0. Results were expressed as a percentage of immobilised animals after $24 \mathrm{~h}$.

\subsection{Chemical analysis}

All parameters representing the typical characteristics of leather tanning industry and treatment efficiency of chemical and biological treatment were measured according to Standard Methods [23] in the CODISO and University of Salerno laboratories. A Whatman GF/C filter paper with $1.2 \mu \mathrm{m}$ pore size was used for total suspended solids (TSS) measurement and effluent $\mathrm{COD}$ analysis. $\mathrm{BOD}_{5}$ was measured without adding any seed (OXI TOP, ISCO, Italy). Influent COD was measured after filtering the sample through $1.2 \mu \mathrm{m}$ filter papers.

All chemicals used in this study were analytical reagent grade. $\mathrm{FeCl}_{3} 6 \mathrm{H}_{2} \mathrm{O}$ and $\mathrm{Al}_{2}\left(\mathrm{SO}_{4}\right)_{3}$ $18 \mathrm{H}_{2} \mathrm{O}$ were obtained from Carlo Erba (Italy). Ferrous chloride and PAFC(PAF 180) were obtained from Chimpex Industries S.p.A. (Italy). The characteristics of PAFC are given in Table 2.

Table 2. Characteristics of PAFC

\begin{tabular}{lc}
\hline Characteristics & Value \\
\hline Appearance & Green \\
Odor & Pungent \\
Density $20^{\circ} \mathrm{C}$ & $1.270-1.320 \mathrm{~g} \mathrm{ml}^{-1}$ \\
$\mathrm{pH} 20^{\circ} \mathrm{C}$ & $2-2.5$ \\
$\mathrm{Fe}^{2+}$ & $60-80 \mathrm{~g} \mathrm{I}^{-1}$ \\
$\mathrm{Al}_{2} \mathrm{O}_{3}$ & $7.0-9.0 \%$ \\
\hline
\end{tabular}




\section{RESULTS AND DISCUSSION}

\subsection{Toxicity and wastewater characterizations}

According to statistical evaluations of inlet and outlet concentrations of COD and TSS parameters of the CODISO during 2002-2003 period, the average inlet COD and TSS concentrations were 7020 and $1520 \mathrm{mg} \mathrm{I}^{-1}$ respectively [24]. These values were in accord with the literature [4]. The average influent chromium (III) concentration was reported as $140 \mathrm{mg} \mathrm{I}^{-1}$ for the same period [12]. The average outlet values of both parameters (450 mg I-1 COD, 150 $\mathrm{mg} \mathrm{I}^{-1}$ TSS) hardly complied with the sewer discharge limits (COD $<500 \mathrm{mg} \mathrm{l}^{-1}$, TSS $<200 \mathrm{mg}^{-1}$ $\left.\mathrm{I}^{-1}[19]\right)$. In that period, raw (R), coagulated (CF), biological effluent (B) wastewater samples and the conditioned sludge (CS) taken from the CODISO showed a toxicity ranking of effluents as CS >CF $\geq R>>B$ on sea urchins and marine micro algae for the wastewater characteristics given in Table 3 [12]. The toxicity in CF sample was attributed to the residual $\mathrm{Al}(\mathrm{III})$ and $\mathrm{Fe}$ (III) considering the previous findings [25,26].

Figure 1 shows the immobilization $D$. magna exposed to the coagulated effluents at different dilutions. The samples (S1.. S6) collected between 2002-2003 displayed 100\% immobilization at $50 \%$ dilution. There was a significant decrease in toxicity of only S3 at $87.5 \%$ dilution. After $93.75 \%$ dilution the toxicity of all samples decreased and at $96.25 \%$ dilution all samples displayed less than $50 \%$ immobilization.

Table 3. Characterization of the wastewater samples from CODISO treatment plant [12]

\begin{tabular}{|c|c|c|c|c|c|c|c|c|}
\hline $\begin{array}{l}\text { Parameter } \\
\text { / Sample }\end{array}$ & $\mathrm{pH}$ & $\begin{array}{l}\text { COD } \\
\left(\mathrm{mg} \mathrm{l}^{-1}\right)\end{array}$ & $\begin{array}{c}\text { TSS } \\
\left(\mathrm{mg} \mathrm{l}^{-1}\right)\end{array}$ & $\begin{array}{c}\mathrm{SO}_{4}^{--} \\
\left(\mathrm{mg} \mathrm{l}^{-1}\right)\end{array}$ & $\begin{array}{l}\mathrm{NH}_{4}-\mathrm{N} \\
\left(\mathrm{mg} \mathrm{l}^{-1}\right)\end{array}$ & $\begin{array}{c}\mathrm{Cl}^{-} \\
\left(\mathrm{mg} \mathrm{l}^{-1}\right)\end{array}$ & $\begin{array}{c}\mathrm{Al} \\
\left(\mathrm{mg} \mathrm{l}^{-1}\right)\end{array}$ & $\begin{array}{c}\mathrm{Fe} \\
\left(\mathrm{mg} \mathrm{l}^{-1}\right)\end{array}$ \\
\hline $\mathrm{R}$ & $4-5$ & $6475-7085$ & $1400-1800$ & $1640-1790$ & $56-71$ & $2550-3050$ & 11.36 & 6.69 \\
\hline $\mathrm{CF}$ & 8.3-8.5 & $2380-2700$ & $200-300$ & -- & $60-67$ & $2340-3000$ & $30-50$ & $20-35$ \\
\hline B & $8-8.2$ & $300-510$ & $80-220$ & $1000-1550$ & $30-34$ & $2020-2340$ & $1-1.8$ & $0.7-1.1$ \\
\hline
\end{tabular}

R: raw wastewater; CF: post coagulation-flocculation; B: post biological treatment

\subsection{Coagulation experiments}

With the scope of the improvement of coagulation efficiency and reduce the toxicity, raw wastewater samples were taken from the CODISO in February (A) and June (B and C), 2005 (Table 4). The chemical parameters and toxicity results are shown in Table 4. As expected that the difference between Total $\left(6855 \mathrm{mg} \mathrm{l}^{-1}\right)$ and filtered COD $\left(1920 \mathrm{mg} \mathrm{l}^{-1}\right)$ values in accord with the high TSS value $\left(2865 \mathrm{mg} \mathrm{l}^{-1}\right)$ on the first sample (A). Raw wastewater displayed $100 \%$ immobilization even at $25 \%$ dilution. High ammonia concentration (70.5) contributed to the influent toxicity up to $50 \%$ dilution $\left(35 \mathrm{mg} \mathrm{l}^{-1}\right)$ [22], however, the $100 \%$ immobilization at $25 \%$ dilution can be explained due to the complex mixture toxicity of various recalcitrants present in wastewater. More than $75 \%$ of COD removal was obtained at all doses and combinations of the coagulants in accord with the previous findings [4,5].

As shown in Figure $3 a$, there was only $2 \%$ shift in COD removal when PAFC dose varied from 800 to $1200 \mathrm{mg} \mathrm{l}^{-1}$ at $9.0 \mathrm{pH}$ while the immobilization of $D$. magna decreased from 80 to $40 \%$ (Figure 3b).

As seen in Figure $4 \mathrm{a}$, the PAFC and $\mathrm{Ca}(\mathrm{OH})_{2}$ combination proved higher $\mathrm{COD}$ removal than PAFC use alone, and COD removal efficiency of PAFC decreased by its elevated dose (1200 $\mathrm{mg}^{-1}$ ) vs pH (Sample A). Both 900 and $1200 \mathrm{mg} \mathrm{l}^{-1}$ PAFC doses resulted in high (>70\%) $D$. magna immobilization at $8.0 \mathrm{pH}$ while all coagulation experiments displayed less than $50 \%$ immobilization at $8.5 \mathrm{pH}$ (Figure $4 \mathrm{~b}$ ).

In accord with the higher COD removal the supernatants of $\mathrm{PAFC}+\mathrm{Ca}(\mathrm{OH})_{2}$ combination coagulated samples showed lesser immobilization than PAFC used alone at $9.0 \mathrm{pH}$. Increasing $\mathrm{pH}$ from 8.5 to 9.0 shifted COD removal at 5\% more for all doses of $\mathrm{PAFC}+\mathrm{Ca}(\mathrm{OH})_{2}$ combination (Figure $5 \mathrm{a}$ ) while TSS removal fluctuated and varied over $96 \%$ (Fig $5 b$ ). Considering the point that the coagulation process is followed by biological process in the CODISO central treatment plant, $8.5 \mathrm{pH}$ at which all coagulation doses proved less than $50 \%$ of $D$. magna immobilization at $50 \%$ dilution was assessed the optimum one. A dose of $900 \mathrm{mg} \mathrm{l}^{-1}$ PAFC would be satisfying in terms of COD and TSS removal as well as toxicity 
reduction and less sludge amount compared to $\mathrm{Ca}(\mathrm{OH})_{2}$ combination. However, both the removal of metals such chromium and $\mathrm{Al}$, Fe can be enhanced by the use of $\mathrm{Ca}(\mathrm{OH})_{2}$ although chromium was completely removed by the use of $\mathrm{FeCl}_{3}$ alone in a less strong tanning effluent [4].

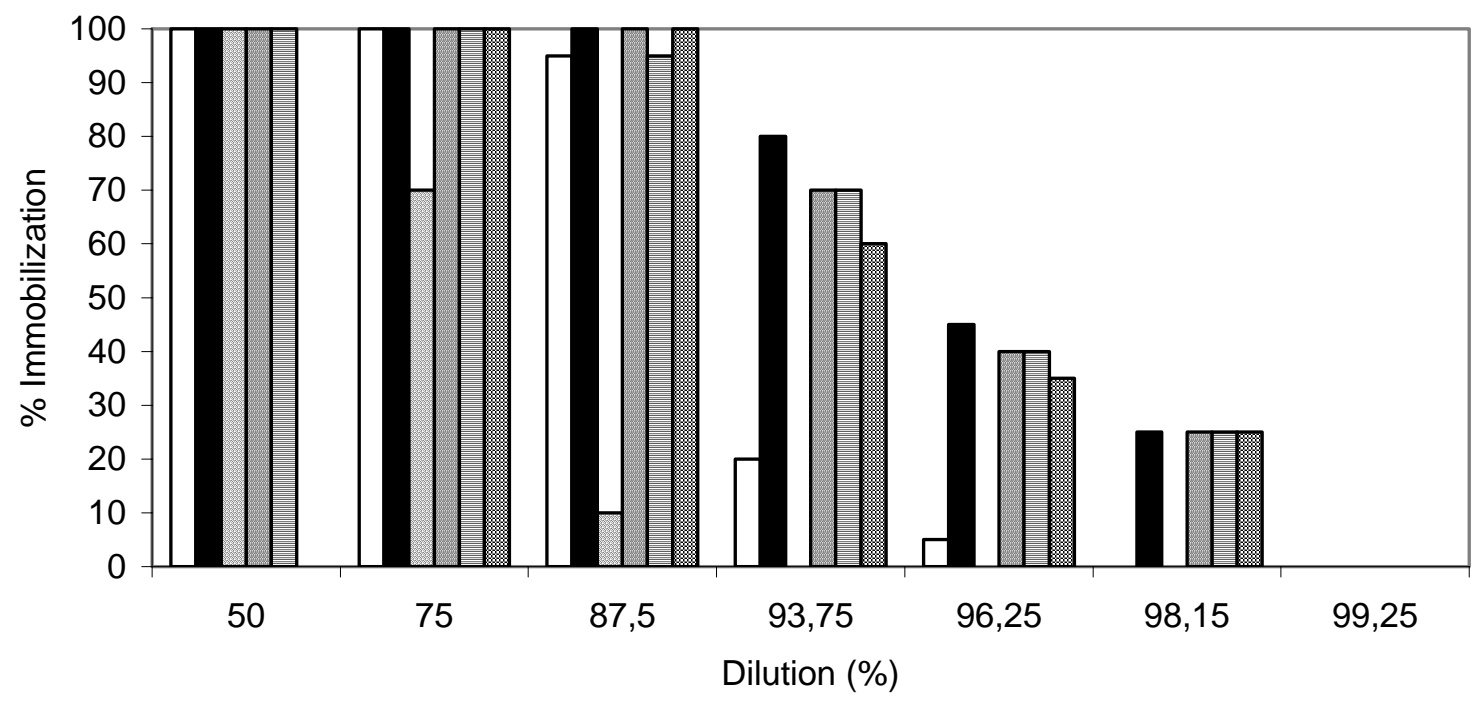

$\square \mathrm{S} 1 \quad \square \mathrm{S} 2 \quad \square \mathrm{S} 3 \quad \square \mathrm{S} 4 \quad \square \mathrm{S} 5 \quad \square \mathrm{S} 6$

Figure 1. The immobilization of D.magna exposed to the effluent of the CF

Table 4. Wastewater characteristics for the samples taken in 2005 *

\begin{tabular}{|c|c|c|c|c|c|c|c|c|}
\hline \multirow[b]{2}{*}{ Parameter } & \multirow[b]{2}{*}{ Unit } & \multicolumn{3}{|c|}{$\begin{array}{c}\mathrm{A} \\
\text { (9 February) }\end{array}$} & \multicolumn{2}{|c|}{$\begin{array}{c}\text { B } \\
\text { (8 June) } \\
\end{array}$} & \multicolumn{2}{|c|}{$\begin{array}{c}\text { C } \\
\text { (23 June) }\end{array}$} \\
\hline & & $\mathrm{R}^{+}$ & EQ & CF & $\mathrm{R}$ & EQ & $\mathrm{R}$ & EQ \\
\hline Total COD & $\left(\mathrm{mg} \mathrm{l}^{-1}\right)$ & 6855 & 16465 & 1895 & 9567 & 12415 & 10410 & 14820 \\
\hline Filtered COD $(1,2 \mu \mathrm{m})$ & $\left(\mathrm{mg} \mathrm{l}^{-1}\right)$ & 1920 & & & & & & \\
\hline $\mathrm{BOD}_{5}$ & $\left(\mathrm{mg} \mathrm{l}^{-1}\right)$ & 2700 & 11860 & 65 & & & & \\
\hline TSS & $\left(\mathrm{mg} \mathrm{l}^{-1}\right)$ & 2865 & & & 3950 & 9200 & 4320 & 10660 \\
\hline Alkalinity & $\left(\mathrm{mg} \mathrm{CaCO}_{3} \mathrm{I}^{-1}\right)$ & 1010 & & 2125 & & & & \\
\hline Chloride & $\left(\mathrm{mg} \mathrm{l}^{-1}\right)$ & 2835 & & & 1985 & & 2980 & 2481 \\
\hline Sulphates & $\left(\mathrm{mg} \mathrm{l}^{-1}\right)$ & 745 & & 55.8 & 1200 & 1000 & 750 & 400 \\
\hline Ammonia & $\left(\mathrm{mgNH}_{4}-\mathrm{N} \mathrm{I}^{-1}\right)$ & 70.5 & & 0.50 & 95 & 95 & 80 & 81 \\
\hline Phosphate & $\left(\mathrm{mg} \mathrm{l}^{-1}\right)$ & & & & 3 & 2 & 3.4 & 2.0 \\
\hline Conductivity & $\left(\mu \mathrm{mho} \mathrm{cm}^{-1}\right)$ & 8600 & 7.70 & 8.43 & & & & \\
\hline $\mathrm{pH}$ & -- & 6.61 & & & & 6.80 & 3.8 & 6.95 \\
\hline
\end{tabular}

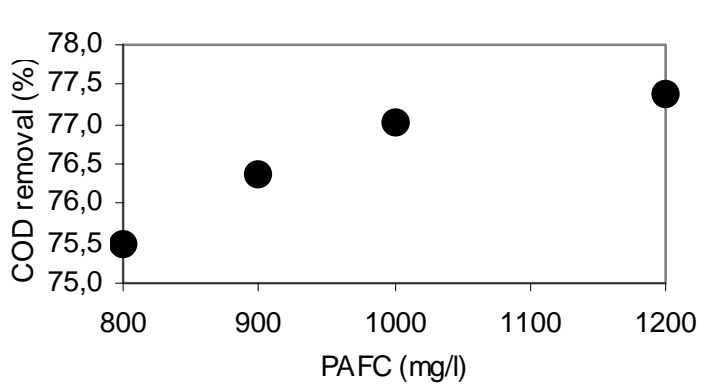

(a)

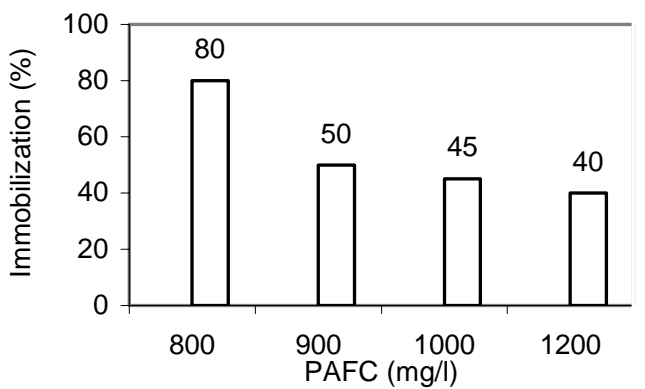

(b)

Figure 3. COD removal (\%) (a) and D. magna immobilization (\%) (b) of PAFC coagulated samples at $9.0 \mathrm{pH}$ and $50 \%$ dilution for the Sample A 
Comparative jar-test experiments using different coagulants (ferric chloride, ferrous chloride, aluminium sulphate and poly-aluminium ferric chloride (PAFC) on the second (B) and third (C) samples taken form EQ (having higher COD than Sample A due to sludge recycling in that time) during 2005 also indicated that the COD removal efficiency by PAFC was higher than the other coagulants. On the other hand, the increase in dose of the coagulants did not improve COD efficiency significantly, on the contrary at higher doses the COD removal decreased (Figures 6 and 7). Thus, $900 \mathrm{mg}^{-1}$ of PAFC is defined optimum dose for the CODISO treatment plant.

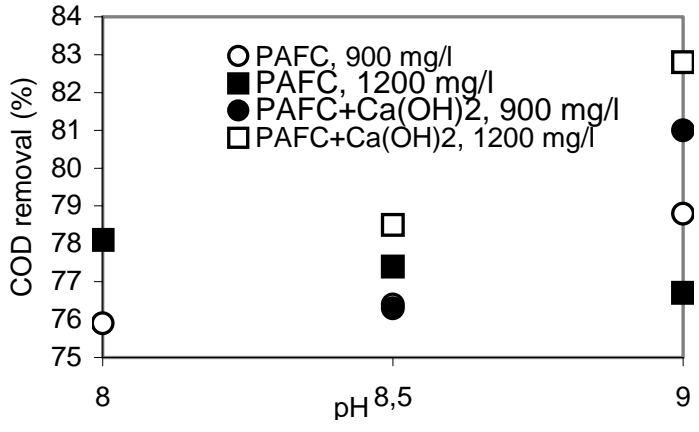

(a)

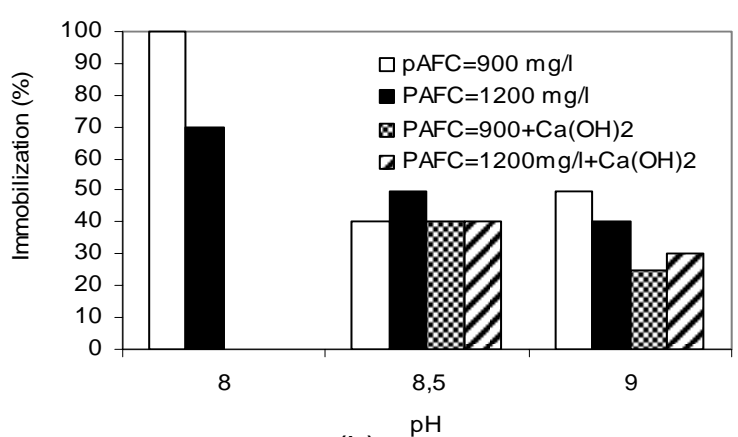

(b)

Figure 4. Comparison of COD removal (\%) (a) and D. magna immobilization (\%) at 50\% dilution (b) among the coagulant doses and $\mathrm{pH}$ values on the Sample $\mathrm{A}$

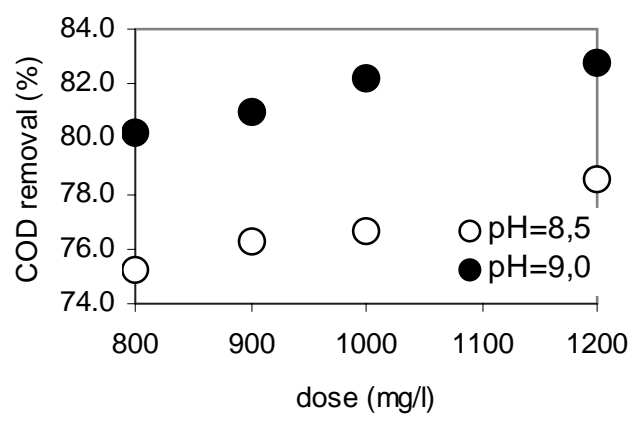

(a)

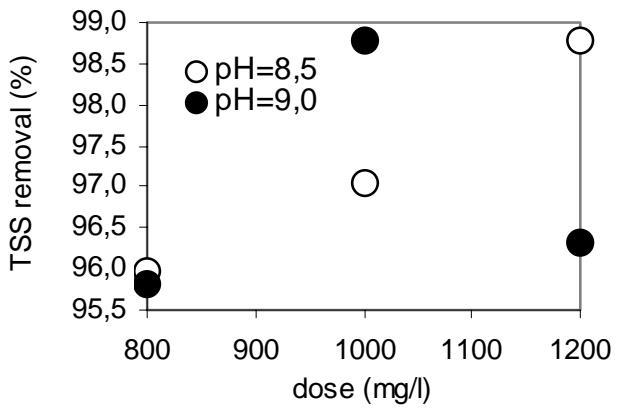

(b)

Figure 5. $\mathrm{COD}(\mathrm{a})$ and TSS (b) removal at $\mathrm{pH} 8,5$ and 9,0 using $\mathrm{PAFC}+\mathrm{Ca}(\mathrm{OH})_{2}$ for the Sample A

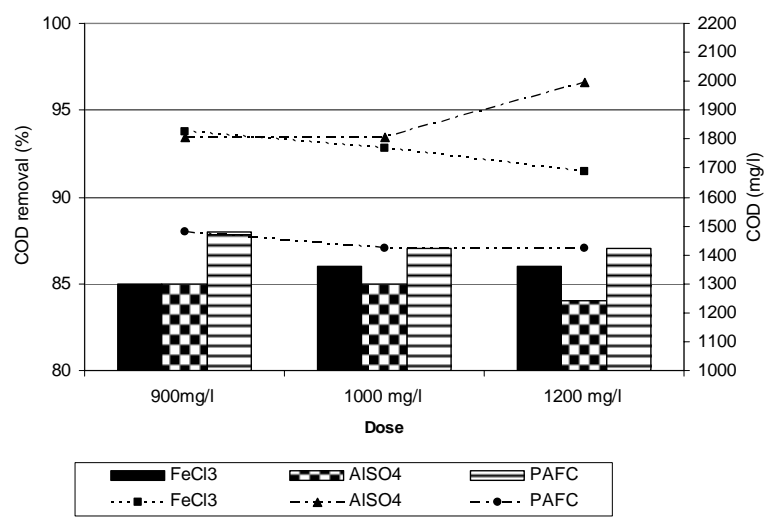

Figure 6. COD removal using different coagulants on the sample taken from equalization tank (Sample B) at $\mathrm{pH} 8,5(\mathrm{pH}$ was adjusted using $\mathrm{NaOH})$

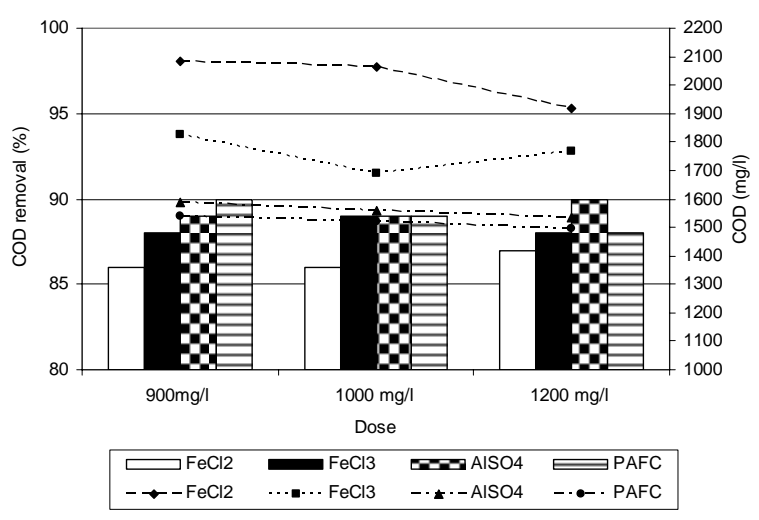

Figure 7. COD removal using different coagulants on the sample taken from equalization tank (Sample C) at $\mathrm{pH} 8,5(\mathrm{pH}$ was adjusted using $\mathrm{NaOH}$ ) 


\section{CONCLUSIONS}

This study aimed to optimize $\mathrm{pH}$ and coagulant dose for the wastewater originated from a leather tanning district (Southern Italy) to improve COD removal as well reduce the toxicity of the existing treatment process. Toxicity was monitored in raw and coagulated samples using D. magna.

The optimum conditions were assessed as $8.5 \mathrm{pH}$ and $900 \mathrm{mg} \mathrm{l}^{-1}$ of PAFC with the $\mathrm{pH}$ adjustment by using $\mathrm{Ca}(\mathrm{OH})_{2}$ which resulted in high removal of COD $(>75 \%)$ and TSS( $\left.>95 \%\right)$ and reduced $D$. magna immobilization ( $<50 \%)$. Once the optimum conditions for PAFC was determined those were compared on two more samples by comparing different coagulants. The second series of Jar-tests also confirmed the conditions defined on the first sample.

The overall decrease in effluent toxicity following the CF effluent suggested an effective removal of toxic components from tannery wastewater, however, the policy of submitting wastewater to biological treatment before its release in receiving water bodies is necessary to reduce toxicity for protecting the aquatic environment.

\section{ACKNOWLEGMENTS}

Thanks are due to Prof. R.M.A. Napoli for his suggestions. The technical assistance by Serafino De Stefano, Rosanna De Maio and Luciano Moffa is appreciated.

\section{REFERENCES}

1. National Leather Tanning Union of Italy (2005) 'www.unic.it'.

2. Jochimsen, J.C., Schenk, H., Jekel, M.R., Hegemann, W. (1997) Combined oxidative and biological treatment for separated streams of tannery wastewater, Wat. Sci. Tech., 36, 209216.

3. Di laconi, C., Ricco, G., Tanzarella, C., Tomei, M.C. (1998) Chemical oxidation combined with biological oxidation in removal of biorefractory compounds, Annali di Chimica, 88, 849-858.

4. Ates, E., Orhon, D., Tunay, O. (1997) Characterization of tannery wastewaters for pretreatment-selected case studies, Wat. Sci. Tech., 36(2-3), 217-223.

5. Kabdasli, I., Tunay, O., Orhon, D. (1999) Wastewater control and management in a leather tanning district, Wat. Sci. Tech., 40(1), 261-267.

6. Song, Z., Williams, C.J., Edyvean, G.J. (2004) Treatment of tannery wastewater by chemical coagulation, Desalination, 164, 249-259.

7. Schrank, S.G., José, H.J., Moreira, R.F.P.M., Schroder, H.Fr. (2004) Elucidation of the behavior of tannery wastewater under advanced oxidation conditions, Chemosphere, 56, 411423.

8. Schrank, S.G., José, H.J., Moreira, R.F.P.M., Schroder, H.Fr. (2005) Applicability of Fenton and $\mathrm{H}_{2} \mathrm{O}_{2} / \mathrm{UV}$ reactions in the treatment of tannery wastewaters, Chemosphere, (in press).

9. Di laconi, C., Di Pinto, A.P., Ricco, Tomei, M.C. (2002) Treatment options for tannery wastewater I: Integrated chemical and biological oxidation, Annali di Chimica, 92, 531-539.

10. Tisler, T., Zagorc-Koncan, J., Cotman, M., Drolc, A. (2004), Toxicity potential of disinfection agent in tannery wastewater, Water Res., 38, 3503-3510.

11. E. De Nicola, M. Gallo, M. Iaccarino, S. Meriç, R. Oral, T. Russo, T. Sorrentino, O. Tünay, E. Vuttariello, M. Warnau, G. Pagano, (2004). Hormetic vs. toxic effects of vegetable tannin in a multi-test study. Arch. Environ. Contam. Toxicol, 46, 336-345.

12. Meriç, S., De Nicola, E., laccarino, M., Gallo, M., Di Gennaro, A., Morrone, G., Warnau, M., Belgiorno, V., Pagano, G. (2005) Toxicity of leather tanning wastewater effluents in sea urchin early development and in marine microalgae, Chemosphere, 61(2), 208-217.

13. Rossini, M., Garrido, J.G., Galluzzo, M. (1999) Optimization of the coagulation-flocculation treatment: Influence of rapid mix parameters, Wat. Res., 33(8), 1817-1826.

14. Meriç, S., Guida, M., Mattei, M., Anselmo, A., Melluso, G. (2002) Evaluation of coagulation flocculation process for S. Giovanni a Teduccio municipal wastewater treatment plant, Fresenius Envir. Bull., 11, 906-909.

15. Selçuk, H., Kaptan, D., Meriç, S. (2004) Coagulation of textile wastewater using alum and $\mathrm{Fe}(\mathrm{III})$ salts', Fresenius Environ. Bull., 13(10), 1045-1048.

16. Gao, B.Y., Yue, Q., Wang, B. (2004) Coagulation efficiency and residual aluminum content of ployaluminum silicate chloride in water treatment, Acta Hydrochim. Hydrobiol., 32, 125-130. 
17. Gao, B.Y., Hahn, H.H., Hoffmann, E. (2002) Evaluation of aluminum-silicate polymer composite as a coagulant for water treatment, Wat. Res., 36, 3573-3581.

18. Gao, B.Y., Q. Yue, Q., Miao, J. (2003) Evaluation of polyaluminium ferric chloride (PAFC) as a composite coagulant for water and wastewater treatment, Wat. Sci. Tech., 47(1), 127-132.

19. Italian Official Journal, 124, 29/5/99, suppl. ord. n. 101/L, 1999.

20. ISO (1996) Water quality: determination of the inhibition of the mobility of Daphnia magna Starus (cladocera, Crustacea)- Acute toxicity test, ISO(International Organisation for Standardisation, Geneva, Switzerland) 66431.

21. Villegas-Navarro, A., Ramiez,-M.Y., Salvador, M.S., Gallardo, J.M. (2001) Determination of wastewater $\mathrm{LC}_{50}$ of the different process stages of the textile industry, Ecotox. Environ. Saf., 48, 56-61.

22. Marttinen, S.K., Kettunen, R.H., Sormunen, K.M., Soimasuo, R.M., Rintala, J.A. (2002) Screening of physical-chemical methods for removal of organic material, nitrogen and toxicity from low strength landfill leachates, Chemosphere, 46, 851-858.

23. Standard Methods for the Examination of Water and Wastewater (1998) $20^{\text {th }}$ edition, American Public Health Association/American water Works Association/Water Environment Federation, Washington DC, USA.

24. De-Feo, G., Rizzo, L.., Belgiorno, V., Meric, S. (2006) Potential reuse of a leather tanning and an urban wastewater treatment plant effluent in Italy, Int.J.Environ. Poll. (in press).

25. Pagano, G., His, E., Beiras, R., De Biase, A., Korkina, L.G., laccarino, M., Oral, R., Quiniou, F., Warnau, M., Trieff, N.M. (1996) Cytogenetic, developmental and biochemical effects of aluminium, iron and their mixture in sea urchins and mussels, Arch. Environ. Contam. Toxicol., 31, 466-474.

26. Melluso, G., Guida, M., Mattei, M.L., Pagano, G., Meriç, S. (2004) Daphnia magna and Selenastrum capricornutum in evaluating the toxicity of alum and polymer used in coagulation-flocculation, Fresenius Envir. Bull., 13 (11b), 1244-1247. 